\title{
Confirmation that the Novel Cercozoa Phytocercomonas venanatans Is the Cause of the Disease Chlorotic Streak in Sugarcane
}

\author{
Kathryn S. Braithwaite, ${ }^{\dagger}$ Chuong N. Ngo, and Barry J. Croft
}

First and second authors: Sugar Research Australia, Indooroopilly, QLD 4068, Australia; and third author: Sugar Research Australia, Woodford, QLD 4514, Australia.

Accepted for publication 16 November 2017.

\begin{abstract}
A cercomonad, named Phytocercomonas venanatans, is confirmed as the cause of the sugarcane disease chlorotic streak. This was achieved by establishing aseptic liquid cultures of the pathogen isolated from internal pieces of sugarcane stalk tissue. Actively motile cultures of the pathogen were inoculated into sugarcane roots, stalks, and leaf whorls. Infected plants subsequently developed the characteristic symptoms of chlorotic

streak. Infection was confirmed by PCR screening of plant tissues and by reisolation of the pathogen into aseptic culture followed by PCR and microscopic confirmation. $P$. venanatans is the first reported pathogenic cercomonad able to systemically infect higher plants and the first plant pathogenic cercozoan able to be successfully grown in axenic culture on common microbiological media.
\end{abstract}

Chlorotic streak of sugarcane (Saccharum spp. hybrids) has a worldwide distribution and is one of the most widespread diseases of the Australian sugar industry (Magarey 2005). The disease occurs in areas of high rainfall and poorly drained fields and is a limitation to productivity, particularly during seasons that are wetter than average. Symptoms on leaves appear as yellowish to creamy-white streaks with wavy, irregular margins (Egan 1989). Ash-gray necrotic areas can appear in older streaks. Leaf tips may have a scalded appearance. Infection reduces germination of stalk cuttings, ratooning, stalk number and weight, and is responsible for premature replanting and the loss of highly productive but susceptible cultivars. The disease can cause yield losses of up to $40 \%$ of sugar yield in susceptible cultivars, costing the industry \$AUD 8 to 10 million annually (Magarey and Nielsen 2002). Despite its importance, research progress has been extremely slow due to its intractable nature. The disease is spread through wet soil, flood, and drainage water and infection takes place through the root system, but the root/soil/water environment is difficult to study and control. In the field, leaf symptoms are often transient, with the erratic behavior believed to be due to environmental conditions, including soil temperature (Sturgess 1961).

Although the disease was first recognized simultaneously in Java, Australia, and Hawaii around 1929 (reviewed by Martin 1935), the causal agent was unknown until recently. A range of organisms had been proposed as the causal agent, including a chytrid fungus (Carpenter 1940) or a disease agent vectored by the leafhopper Draeculacephala portola (Abbott and Ingram 1942). Later research clearly established the role of soil and water in disease transmission, rather than an insect (Antoine 1957; Bird et al. 1958). Transmission experiments carried out in the 1960s indicated a virus, but as no vector could be identified, it was thought that the virus must be carried in a free state in soil water (Sturgess 1961).

${ }^{\dagger}$ Corresponding author: K. Braithwaite;

E-mail: kbraithwaite@sugarresearch.com.au

Funding: This research was supported by funding from Sugar Research Australia (project 2013357) and the Queensland Government Department of Agriculture and Fisheries.

(c) 2018 The American Phytopathological Society
With access to low-cost modern sequencing technologies (high throughput sequencing, HTS), we considered it timely to reopen investigations into the causal agent of chlorotic streak. An earlier breakthrough was the identification of a chlorotic streak-specific DNA fragment, which in turn led to the development of a firstgeneration polymerase chain reaction (PCR) diagnostic test (Braithwaite and Croft 2013). The target gene (actin) was too conserved to assist in identifying the causal agent, but it indicated that it was a eukaryote (Braithwaite and Croft 2013). Our hypothesis was that the causal agent belonged to one of three groups of organisms that contain plant pathogens; all produce motile spores and all involve infection through water: either the Cercozoa (Rhizaria), the Oomycetes (Stramenopiles), or the Chytrids (Fungi). The complete ribosomal DNA coding region was then identified in the DNA sequencing (DNAseq) data, indicating that the putative causal organism was a novel cercozoan (=Cercozoa). Ribosomal 18S and 28S DNA phylogenies confirmed that the novel cercozoan belonged to the order Cercomonadida (=phylum Cercozoa, supergroup Rhizaria) (Ngo et al. 2018). The complete actin gene and partial polyubiquitin gene sequences provided additional taxonomic support.

A novel biflagellated cercomonad was isolated from diseased sugarcane stalks and established in pure culture. A taxonomic diagnosis of the organism has been presented in Ngo et al. (2018) and the cercomonad has been named Phytocercomonas venanatans Ngo, Braithwaite, and Bass. Through amplicon sequencing, Ngo et al. (2018) was able to show a consistent link between $P$. venanatans $18 \mathrm{~S}$ ribosomal DNA and diseased sugarcane samples representing different plant tissues and collected from different locations in Australia. Here, we report on efforts to optimize the growth of $P$. venanatans in pure culture, the use of the cultured organism to infect sugarcane plants, and the reisolation of the organism from infected plants, thus completing Koch's postulates and confirming that $P$. venanatans causes the disease chlorotic streak in sugarcane.

\section{MATERIALS AND METHODS}

Isolation and culturing of $\boldsymbol{P}$. venanatans. Source material for the original $P$. venanatans isolations were the chlorotic streak diseased sugarcane cultivars Empire, RP193-67, and Q238(b, maintained in the field at the SRA Pathology Farm at Woodford, Queensland. The infected cultivars, known to be highly susceptible 
to chlorotic streak, were originally sourced from Broadwater (northern New South Wales), Woodford (southern Queensland) and Mackay (central Queensland), respectively. Individual stalks were only selected for pathogen isolation if their leaves displayed strong visual symptoms of the disease, namely long creamy-white to yellow diffuse stripes, often with necrotic regions within the stripe (Fig. 1A). Later, $P$. venanatans isolations were made from experimentally inoculated plants. A control culture was established from uninfected cultivar KQ228(D)

Sugarcane stalk lengths were washed and scrubbed thoroughly, sprayed with ethanol, and under sterile conditions, recut and split longitudinally. Small pieces of internal stalk tissue were removed from the node regions and transferred initially to S8 broth media (Davis et al. 1980) in Nunc Cell Culture Treated Eas YFlasks (Thermo Fisher Scientific, Waltham, MA). Cultures were incubated at $28^{\circ} \mathrm{C}$ in the dark without shaking. Culturing success was assessed by checking flask cultures on an Olympus CK 2 inverse microscope or counting cells on a hemocytometer under an Olympus BX50 light microscope, both at magnifications up to $400 \times$, and by PCR. Cell counts were determined by immobilizing $10 \mu \mathrm{l}$ of cells on a hemocytometer with the addition of $1 \mu \mathrm{l}$ of $4 \%$ paraformaldehyde. P. venanatans is identified microscopically as round to ovoid to drop shaped cells, 6 to $15 \mu \mathrm{m}$ long, with two flagella extending in opposite directions (Ngo et al. 2018).

Growth curves were established for freshly initiated cultures and subcultures. Two stalks of the infected RP193-67 were used to initiate replicate cultures of $P$. venanatans in S8 broth medium and cell counts were taken at various time points over 4 weeks. The best culture was subcultured into two media, S8 broth and corn meal broth 6 days after the original initiation. Corn meal broth was prepared by boiling $40 \mathrm{~g}$ of food-grade polenta per liter deionized water, followed by filtering through a sieve to remove the particulate matter. Three replicate cultures were prepared for each media, each inoculated with a fixed volume of inoculum $(0.2 \mathrm{ml}$, giving approximately 17,444 cells $/ \mathrm{ml}$ ). Cell counts were taken at various time points over 3 weeks.

A second experiment was performed to determine the optimal growth media. Cultures were initiated from an infected stalk of RP193-67 into S8 broth. Subculturing was performed in the common microbiological media, corn meal both and potato dextrose broth, with or without supplemented peptone at $4 \mathrm{~g} /$ liter. The peptone, a mixed-sourced animal peptone, was supplied by Amyl Media,
Dandenong, Victoria, Australia. Potato dextrose broth was prepared by boiling $200 \mathrm{~g}$ of washed white potatoes per liter deionized water and filtering through a sieve to remove the particulate matter. Glucose at $20 \mathrm{~g} /$ liter was then added. A simple media of glucose (20 g/liter) plus peptone ( $4 \mathrm{~g} / \mathrm{liter})$ was also tested. All subcultures were seeded with approximately 50,000 cells $/ \mathrm{ml}$ from the original $\mathrm{S} 8$ culture. Cell counts were averaged across six replicate flasks.

Inoculation experiments. Chlorotic streak disease-free (healthy) sugarcane material for inoculations was prepared by exposing single-bud stalk cuttings to a hot water treatment of $50^{\circ} \mathrm{C}$ for $30 \mathrm{~min}$ (Egan 1989). The bud cuttings were then germinated in vermiculite and transplanted to commercial potting mix and maintained in a glasshouse. We used the cultivars Empire, RP193-67, Q183(') and Q90, sourced from the SRA Pathology Farm at Woodford. To demonstrate Koch's postulates, cultures of $P$. venanatans were used to inoculate chlorotic streak-free sugarcane plants by several methods.

Inoculation experiment 1. Injection into shoot roots. Disease-free single-bud stalk cuttings of Q90 were planted into long flat-sided pots. The pots were made from plastic conduit split in half lengthways with the open face covered with clear, removable Perspex to allow access to the roots (Pearson et al. 1996). When the plants were 3 months old and approximately $80 \mathrm{~cm}$ in height to the first visible dewlap leaf, the Perspex plate was removed and $0.2 \mathrm{ml}$ of one of three culture preparations were injected with a hypodermic syringe into any thick white shoot roots visible on the soil surface (Fig. 1B). The three culture preparations, all grown in S8 broth, comprised (i) a fresh, actively motile 6-day-old culture established from chlorotic streak-infected Empire, (ii) an inactive (nonmotile) 1-month-old subculture originally established from chlorotic streak-infected RP193-67, and (iii) a control cell-free culture derived from uninfected KQ228 ${ }^{(}$. Two plants were inoculated per treatment. For this initial trial, there was no attempt to quantify the inoculum, as only the growth state of the cultures was being compared. Plants were later transferred to 20-liter pots and grown on the glasshouse floor.

Three further experiments were conducted where test plants were inoculated by injecting known amounts of $P$. venanatans cells into either the roots, stalks or leaf whorls. Plants were inspected weekly and the time for symptom development recorded. Reisolation of $P$. venanatans was attempted from plants showing symptoms, followed by microscopic confirmation.
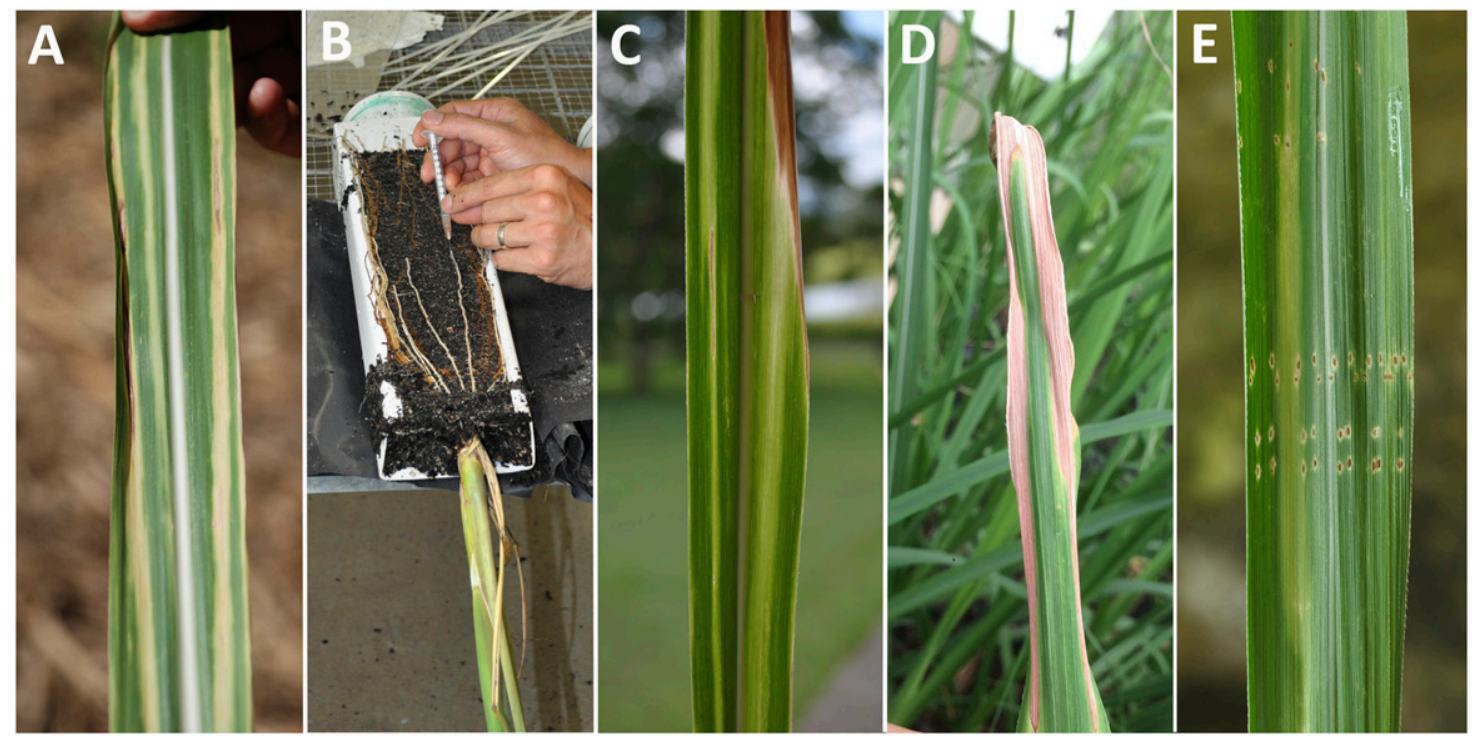

Fig. 1. Demonstration of Koch's postulates for chlorotic streak in sugarcane. A, Typical symptoms of chlorotic streak in field-grown sugarcane leaves, seen as creamy-white streaks with diffuse edges and necrosis within the streaks. B, Injecting a Phytocercomonas venanatans culture into the shoot roots of sugarcane cultivar Q90. C, Leaf symptoms observed after an active culture of P. venanatans was injected into Q90 shoot roots. D, Severe scalding and necrosis seen after applying a $P$. venanatans culture to the top of a decapitated RP193-67 stalk. E, Mild leaf streaking and injection holes seen in the unfurled leaf of RP193-67 after injecting the leaf whorl with a $P$. venanatans culture. 
Inoculation experiment 2. Injection into shoot roots. Disease-free single-bud stalk cuttings of cultivars Empire and Q183(b) were germinated in 700-ml pots. When 2 months old, the root mass was removed from the original pot and any thick shoot roots on the surface of the root mass were injected with a total volume of $0.3 \mathrm{ml}$ of a $P$. venanatans culture with a hypodermic syringe. Plants were immediately transplanted to larger 5-liter pots. The culture, established from chlorotic streak-infected Q238 (b into S8 broth, was 12 days old at the time of inoculation with approximately 790,000 actively motile cells $/ \mathrm{ml}$ (based on hemocytometer cell counts). Control plants were injected with S8 broth. Three plants were inoculated per treatment.

Inoculation experiment 3. Stalk injection. Disease-free single-bud stalk cuttings of RP193-67, Empire, and Q183(b) were germinated and grown for 5 months, by which time the plants had produced stalks approximately 20 to $30 \mathrm{~mm}$ in diameter. The plants were inoculated by injecting $0.1 \mathrm{ml}$ of a $P$. venanatans culture with a hypodermic syringe into each of three holes made with a fine needle in the root primordial region of the basal node of the stem. The culture was established from the severely infected Q183( ${ }^{(b)}$ plant inoculated in experiment 2 through root injection. The culture was grown in S8 broth for 13 days and had approximately 410,000 cells $/ \mathrm{ml}$. Control plants were injected with S8 broth. Two plants were inoculated per treatment.

Inoculation experiment 4. Leaf whorl inoculations. Diseasefree single-bud stalk cuttings of RP193-67 were germinated and grown for 3 months. One set of three plants was inoculated by decapitating the shoot above the growing point with a pair of sharp secateurs and applying $0.2 \mathrm{ml}$ of $P$. venanatans culture to the freshly cut surface of the leaf whorl. Another set of three plants was inoculated by injecting $0.1 \mathrm{ml}$ of culture into each of three holes made with a syringe into the leaf whorl above the growing point of the shoot. The inoculum was a subculture of that used in experiment 3 and grown for 7 days in S8 broth to give approximately 42,000 cells $/ \mathrm{ml}$. Two control plants received no inoculation.

PCR detection of $\boldsymbol{P}$. venanatans. PCR templates were prepared using a DNeasy Plant mini kit (Qiagen, Hilden, Germany) for both sugarcane stalk pieces and cell cultures. For cell cultures, 100- $\mu \mathrm{l}$ aliquots were centrifuged for $5 \mathrm{~min}$ at $15,000 \times g$ and the pellet resuspended in buffer AP1 supplied with the kit, then extracted according to manufacturer's instructions.

PCR primers CS18SF1 and CS18SR2, specific for the causal organism of chlorotic streak and based on the $P$. venanatans ribosomal small subunit (SSU), were used for gel-based PCR screening (Table 1). PCR amplification with GoTaq Green master mix (Promega, Madison, WI) was performed on a Mastercycler proS (Eppendorf, Hamburg, Germany) or Veriti (Applied Biosystems, Foster City, CA) thermocycler. The cycling program was $95^{\circ} \mathrm{C}$ for $5 \mathrm{~min}$, followed by 35 cycles of $95^{\circ} \mathrm{C}$ for $30 \mathrm{~s}, 60^{\circ} \mathrm{C}$ for $1 \mathrm{~min}$ and $72^{\circ} \mathrm{C}$ for $30 \mathrm{~s}$, and then a final cycle of $72^{\circ} \mathrm{C}$ for $2 \mathrm{~min}$. PCR screening was always combined with one of two endogenous tests. Sugarcane DNA samples were checked with primers targeting phosphofructokinase (PFK5), while cell culture DNA was checked with universal SSU primers (Table 1).

Quantitative PCR (qPCR) primers targeting the ribosomal SSU of both the pathogen and host, were used to quantify relative abundance of the pathogen (Table 1). qPCR was performed on a ViiA 7 Real-Time PCR system (Applied Biosystems) with SensiMix SYBR Low-ROX (Bioline, Alexandria, New South Wales, Australia). An annealing temperature of $60^{\circ} \mathrm{C}$ was used for all qPCR. Pathogen (CS) to host (So) cycle threshold $(\mathrm{Ct})$ values were compared to

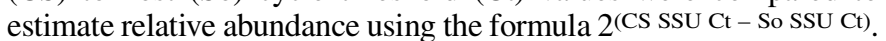

The relative pathogen level within six mature symptomatic fieldgrown stalks of cultivar RP193-67 was determined using qPCR. The nodes of the six stalks were numbered from the top down, then the stalks split longitudinally. Three different pieces of internal tissue were removed from five to seven nodal regions per stalk, depending on the stalk length. Independent DNA extractions were performed for the three node pieces using the Qiagen DNeasy Plant mini kit as described previously. qPCR was performed in triplicate to provide technical replicates.

\section{RESULTS}

Determination of growth curves for the organism in culture. Replicate cultures of $P$. venanatans were initiated from infected RP193-67 and cell numbers were monitored over 4 weeks. Figure 2A shows that one culture (S8 1-2 from stalk 1, replicate flask 2) was found to have extremely high cell counts, relative to the others. Motile cells increased in number for 6 to 13 days after culture S8 1-2 was initiated, reaching a peak of $3.7 \times 10^{6} \mathrm{cells} / \mathrm{ml}$ and then started to reduce in number. This coincided with increasing numbers of nonmotile cells without flagella. By comparison, the next best culture (S8 1-1 from stalk 1, replicate flask 1) had reached only $8.6 \times 10^{4}$ cells $/ \mathrm{ml}$ after 13 days.

The high cell count culture (S8 1-2) was subcultured 6 days after the original initiation and cell numbers were monitored over a further 3 weeks. Figure 2B shows that the number of motile cells in S8 subcultures increased for about 7 days and then started to decline. The numbers of motile cells in corn meal broth subcultures declined after 16 days. The variation in cell number among individual subcultures was much less than that observed in initiated cultures.

For both the initial isolation and subculture, we determined that between 7 to 14 days was the period of peak growth. The next experiment was performed to determine the optimal growth media. Cultures initiated from cultivar RP193-67 into S8 broth were subcultured into corn meal broth and potato dextrose broth, either alone or supplemented with peptone. S8 medium and a simple medium of glucose and peptone were also included. The optimal media was potato dextrose broth supplemented with peptone (Fig. 3). Even

TABLE 1. PCR primers used for detection and quantification for Phytocercomonas venanatans

\begin{tabular}{lllc}
\hline Test and target gene & Primers & \multicolumn{1}{c}{ Nucleotide sequence $\left(5^{\prime}-3^{\prime}\right)$} & $\begin{array}{c}\text { Amplified } \\
\text { length (bp) }\end{array}$ \\
\hline $\begin{array}{l}\text { Diagnostic test for } P \text {. venanatans } \\
\text { Small subunit (SSU) }\end{array}$ & CS18SF1 & GGGCGTTTATACGTCTGGTA & 581 \\
Endogenous test for sugarcane & CS18SR2 & CGGATGATCTGCAGTTGGTA & This study \\
PFK5 & ScPFK5F1 & AGCCACATCAGATCAACAAG & Zhu et al. (2013) \\
Endogenous test for cell cultures & ScPFK5R1 & TGAAGTTATACCCTGCCATT & 483 \\
Fungal SSU & NS7 & GAGGCAATAACAGGTCTGTGATGC & 377 \\
qPCR for $P$. venanatans & NS8 & TCCGCAGGTTCACCTACGGA & White et al. (1990) \\
SSU & qCS18SF2 & GGTTATCAGCCGAAGGAAGT & 103 \\
qPCR for sugarcane & qCS18SR1 & GTTGTATGCTCGATGCACCT & This study \\
SSU & qSo18SF2 & GGGGGCATTCGTATTTCATA & 112 \\
\hline
\end{tabular}



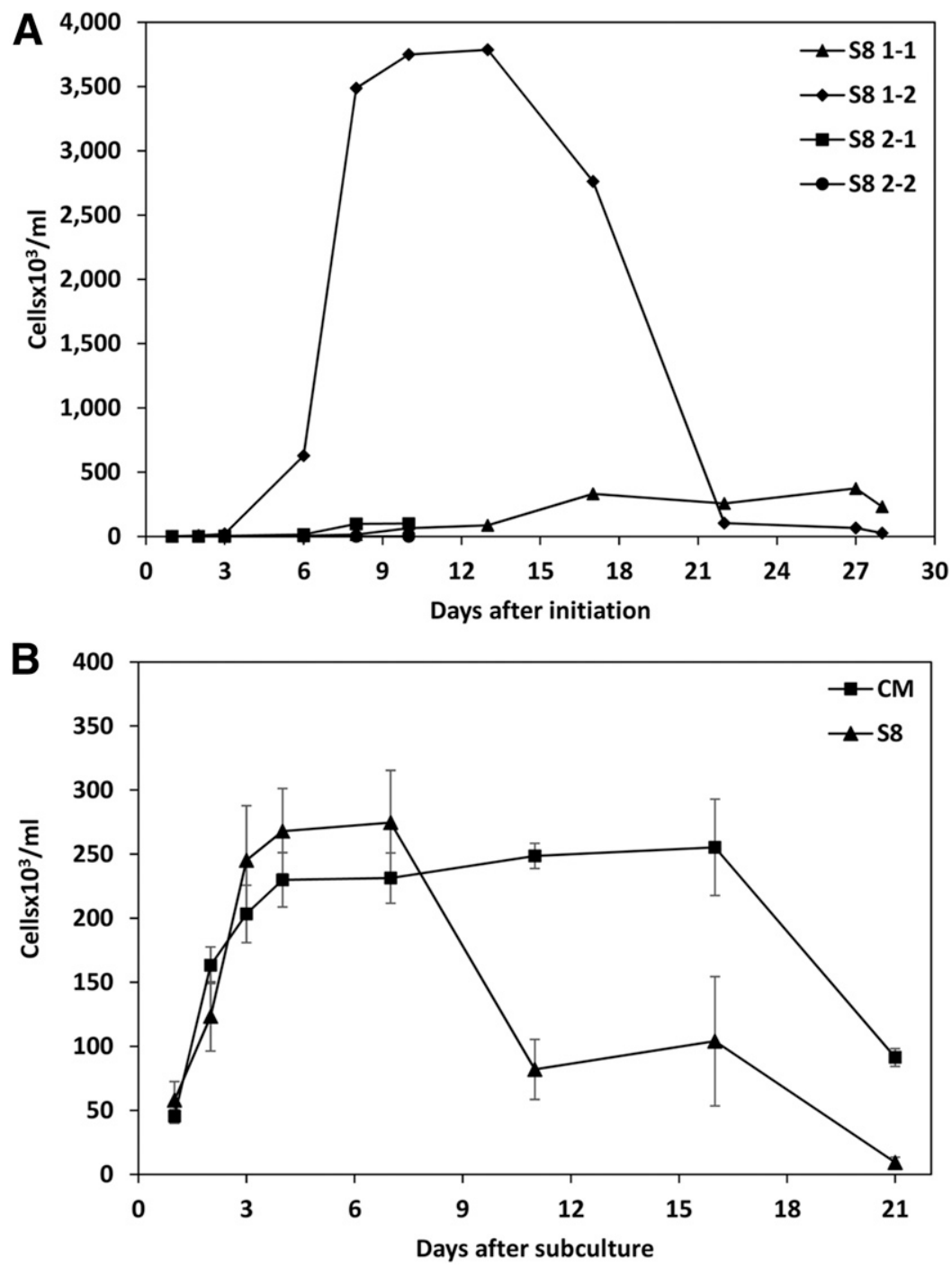

Fig. 2. Variation in growth curves for Phytocercomonas venanatans cultures established from chlorotic streak-infected cultivar RP193-67. A, Four independent, freshly established cultures grown in S8 media over a 4-week period. B, Subcultures of the original stalk 1-2 culture grown in S8 and corn meal (CM) broth over a 3 -week period. Data points represent average \pm standard error of three replicate cultures.

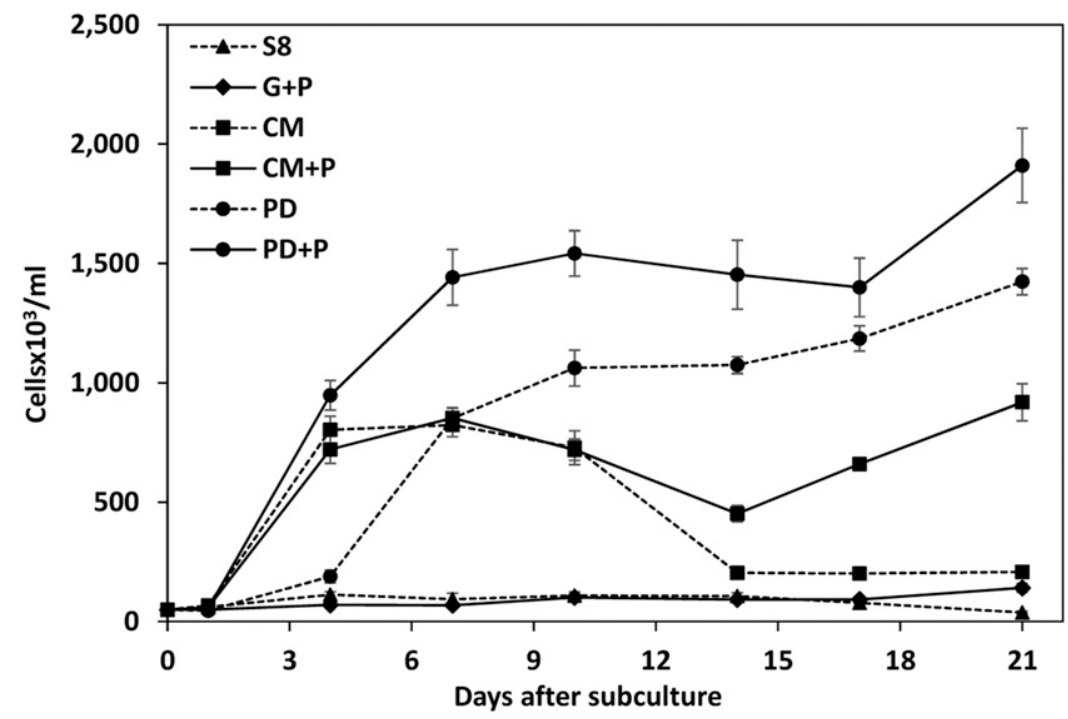

Fig. 3. Growth curves for Phytocercomonas venanatans subcultures grown over a 3-week period in six broth media: $\mathrm{S} 8$, glucose plus peptone $(\mathrm{G}+\mathrm{P})$, corn meal $(\mathrm{CM})$, corn meal plus peptone $(\mathrm{CM}+\mathrm{P})$, potato dextrose $(\mathrm{PD})$, and potato dextrose plus peptone $(\mathrm{PD}+\mathrm{P})$. Solid lines represent media supplemented with peptone $(+\mathrm{P})$ and dashed lines represent media without added peptone. Data points represent average \pm standard error of six cultures per broth medium. 
potato dextrose alone without peptone encouraged higher growth rates than corn meal with peptone. The supplemented potato dextrose broth was so successful that it allowed those cultures to be successively subcultured five times, which could not be achieved in any other media tested (data not shown).

Quantification of $P$. venanatans DNA within RP193-67 stalks. To explain the variation in culturing success when replicate stalk pieces were used to initiate cultures, the pathogen levels within nodes of six stalks of cultivar RP193-67 were estimated. This was done by quantifying $P$. venanatans SSU DNA and sugarcane SSU DNA levels from three replicate nodal tissue pieces with qPCR.
Results are expressed as relative pathogen DNA abundance, calculated by comparing pathogen $\mathrm{Ct}$ values to host $\mathrm{Ct}$ values for the same tissue piece (Fig. 4). Although all six stalks were symptomatic, they varied in their pathogen level. The highest relative pathogen abundance in stalk 5 was almost 50 times higher than in stalk 3 . Individual nodes within a stalk also varied in their pathogen level. For example, within stalk 5 , the seven nodes showed a 60 -fold difference in relative pathogen abundance, while node 5-21 showed a 70-fold difference between the three replicate tissue pieces. There was no apparent trend in abundance of $P$. venanatans along the length of the stalk.
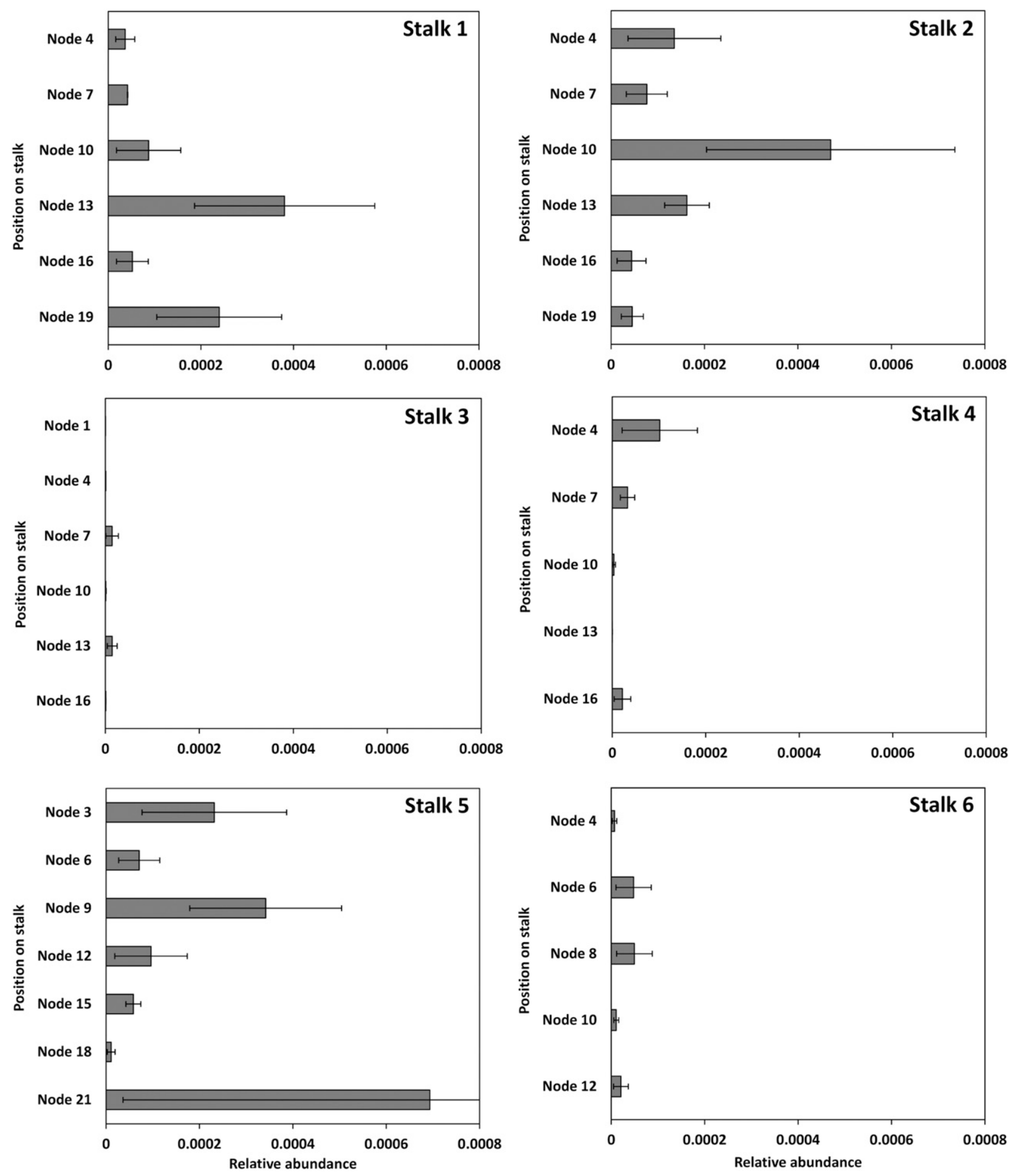

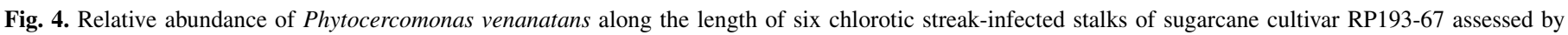

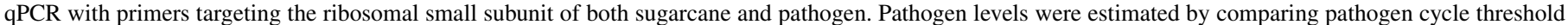
$(\mathrm{Ct})$ values to host $\mathrm{Ct}$ values for the same node tissue piece. Bars represent average \pm standard error of three replicate node pieces. 
Inoculation experiment 1 . Injection into shoot roots. We achieved successful inoculation of sugarcane by injecting individual roots with cultures of $P$. venanatans. A motile cell culture produced chlorotic streak symptoms 6 weeks after inoculation (Table 2). Both replicate plants showed typical symptoms of chlorotic streak, namely leaf streaks with necrosis and scalding on the leaf tips (Fig. 1C). No symptoms were visible on plants injected with the older nonmotile culture or the control culture.

We successfully reisolated $P$. venanatans from the symptomatic plants inoculated with the motile culture. The two replicates were sampled for $P$. venanatans isolations 13 and 16 weeks after inoculation, respectively. For each reisolation, $10 \mathrm{~S} 8$ broth cultures were established using tissue pieces removed from inside the stalks. Stalk material was also sampled for DNA extractions at 13 weeks. The presence of $P$. venanatans was assessed by microscopy and PCR screening of cultures and stalk pieces (Table 2). P. venanatans was not detected in the stalks of plants injected with the inactive or control cultures, nor could successful isolations be made from those plants.

Inoculation experiment 2 . Injection into shoot roots. Root injections were repeated, this time using a known concentration of active cells and different sugarcane cultivars (Table 3 ). Chlorotic streak symptoms were first observed 5 weeks after inoculation and by 10 weeks, one Empire plant had severe symptoms (necrosis and scalding of leaf tips in addition to streaks) and was starting to die. Severe symptoms were also seen in one Q183 ${ }^{(}$plant. No symptoms were seen on control plants. Xylem exudate, collected from $5 \mathrm{~cm}$ stalk pieces by low speed centrifugation, was subjected to PCR screening to confirm the disease status of the inoculated plants (Table 3). Only the two plants with severe symptoms tested PCRpositive and these were used to establish new cultures of $P$. venanatans.

Inoculation experiment 3. Stalk injection. We achieved successful inoculation of sugarcane by injecting stalks with $P$. venanatans. Chlorotic streak symptoms were first observed in the cultivar Empire 7 weeks after inoculation. By 9 weeks, symptoms were observed on all $P$. venanatans inoculated plants of all cultivars and no symptoms were observed on control plants (Table 3). The inoculated plants showed typical leaf streaks, and in some cases necrosis and scalding on the leaf tips. P. venanatans was reisolated from all inoculated plants but not from the control plants. Xylem exudate and stalk pieces were sampled for PCR screening to confirm the disease status of the inoculated plants (Table 3). All plants with symptoms tested PCR-positive and cultures of $P$. venanatans were established from the stalks.

Inoculation experiment 4. Leaf whorl inoculations. In the final trial we achieved infection by inoculating the top of the stalk, specifically the leaf whorl region above the meristem. By applying the inoculum to the cut surface of the top of the stalk, severe symptoms were produced on the newly produced leaves 5 weeks after inoculation. The young leaves had many chlorotic streaks, scorching of the leaf tips and wilting of the young spindle leaves (Fig. 1D). In contrast, the plants that were inoculated by injecting into the leaf whorl showed transitory streak symptoms on the expanding leaf with injection holes only 17 days after inoculation (Fig. 1E). However, only one of the plants went on to develop symptoms in newly produced leaves, taking 12 weeks to appear (Table 4). We saw no symptoms on control plants. P. venanatans was reisolated from the stalks of all inoculated plants showing symptoms, but not from the control plants.

\section{DISCUSSION}

In this report we present methods for the isolation, culturing and inoculation of a novel pathogen of sugarcane, $P$. venanatans and confirm that the organism is the causal agent of the disease chlorotic streak. This is a major breakthrough in the understanding and management of a long-standing disease problem for sugar industries around the world. Compelling circumstantial evidence that a cercomonad was involved in the disease was presented by Ngo et al. (2018), where HTS was used to identify DNA sequences associated with infected sugarcane but absent in healthy sugarcane. A

TABLE 2. Presence of Phytocercomonas venanatans in Q90 test plants after injecting shoot roots with three cultures: a 6-day-old motile culture, a 28-day-old nonmotile culture, and the control medium containing no cells

\begin{tabular}{|c|c|c|c|c|c|}
\hline \multirow{2}{*}{\multicolumn{2}{|c|}{ P. venanatans culture }} & \multicolumn{2}{|c|}{ Q90 test plants } & \multicolumn{2}{|c|}{ P. venanatans cultures established from test plants ${ }^{\mathrm{a}}$} \\
\hline & & \multirow{2}{*}{$\begin{array}{l}\text { Chlorotic streak } \\
\text { symptoms }\end{array}$} & \multirow{2}{*}{$\begin{array}{c}\text { PCR confirmation of } \\
P . \text { venanatans in stalks }\end{array}$} & \multirow{2}{*}{$\begin{array}{l}\text { Microscopic confirmation } \\
\text { of } P \text {. venanatans }\end{array}$} & \multirow{2}{*}{$\begin{array}{l}\text { PCR confirmation } \\
\text { of } P \text {. venanatans }\end{array}$} \\
\hline Status & Replicate & & & & \\
\hline \multirow[t]{2}{*}{ Motile } & A & Streaks and scalding & $10 / 10$ & $10 / 10$ & $10 / 10$ \\
\hline & $\mathrm{B}$ & Streaks and scalding & $n t^{\mathrm{b}}$ & $10 / 10$ & $10 / 10$ \\
\hline \multirow[t]{2}{*}{ Nonmotile } & A & No symptoms & $0 / 10$ & $0 / 10$ & $0 / 10$ \\
\hline & $\mathrm{B}$ & No symptoms & nt & $0 / 10$ & $0 / 10$ \\
\hline \multirow[t]{2}{*}{ Control } & A & No symptoms & $0 / 10$ & $0 / 10$ & $0 / 10$ \\
\hline & B & No symptoms & nt & $0 / 10$ & $0 / 10$ \\
\hline
\end{tabular}

a New isolations were established from the inoculated material and the presence of $P$. venanatans was confirmed by PCR and microscopy.

b nt: not tested.

TABLE 3. Transmission results for sugarcane plants injected with Phytocercomonas venanatans into the shoot roots or stalks

\begin{tabular}{|c|c|c|c|c|}
\hline Inoculum & Test cultivar & $\begin{array}{l}\text { Test plants with } \\
\text { chlorotic steak } \\
\text { symptoms }\end{array}$ & $\begin{array}{l}\text { PCR confirmation } \\
\text { of test plants }\end{array}$ & $\begin{array}{l}\text { Reisolation of } \\
P . \text { venanatans } \\
\text { from test plants }\end{array}$ \\
\hline \multicolumn{5}{|c|}{ Experiment 2: Root Injection } \\
\hline S8 control & Empire & $0 / 3$ & $0 / 3$ & $\mathrm{nt}^{\mathrm{a}}$ \\
\hline S8 control & Q183(D) & $0 / 3$ & $0 / 3$ & nt \\
\hline P. venanatans & Empire & $1 / 3$ & $1 / 3$ & $1 / 1^{\mathrm{b}}$ \\
\hline P. venanatans & Q183( & $2 / 3$ & $1 / 3$ & $1 / 1^{\mathrm{b}}$ \\
\hline \multicolumn{5}{|c|}{ Experiment 3: Stalk injection } \\
\hline S8 control & Empire & $0 / 2$ & $0 / 2$ & $0 / 2$ \\
\hline S8 control & Q183(D) & $0 / 2$ & $0 / 2$ & $0 / 2$ \\
\hline S8 control & RP193-67 & $0 / 2$ & $0 / 2$ & $0 / 2$ \\
\hline P. venanatans & Empire & $2 / 2$ & $2 / 2$ & $2 / 2$ \\
\hline$P$. venanatans & Q183(b) & $2 / 2$ & $2 / 2$ & $2 / 2$ \\
\hline P. venanatans & RP193-67 & $2 / 2$ & $2 / 2$ & $2 / 2$ \\
\hline
\end{tabular}

a nt: not tested.

b Isolation was only attempted from the plants with severe symptoms of chlorotic streak. 
biflagellated cercomonad was subsequently observed in liquid broth cultures established from infected sugarcane stalks. Here, we have improved the culturing conditions for the pathogen and confirmed that it is the cause of the disease by completing Koch's postulates. Using three different inoculation techniques, we have been able to link plant symptoms and plant diagnostic PCR screening with the isolation and reisolation of $P$. venanatans, microscopy and PCR confirmation of the cultures, to strengthen the association between $P$. venanatans and the disease chlorotic streak.

A first-generation diagnostic test was developed by Braithwaite and Croft (2013) and used to screen different sugarcane tissues for the chlorotic streak pathogen. Once the full ribosomal sequence was obtained by Ngo et al. (2018), new diagnostic primers targeting the ribosomal small subunit rather than the actin gene were designed, offering increased sensitivity. The test has been converted to qPCR format to determine the relative amount of $P$. venanatans in sugarcane tissues. Xylem exudate, or stalk vascular extract, collected by applying positive air pressure to stalk pieces (Croft 2002) and stalk tissue were found to be reliable sources of the pathogen (Ngo et al. 2018), offering the potential for a diagnostic test for clean planting material for sugarcane industries.

The ability to successfully grow $P$. venanatans in axenic broth culture is a unique feature for this organism compared with other plant pathogens in the supergroup Rhizaria. Well-known examples include Plasmodiophora brassicae (causing clubroot in brassicas), Spongospora subterranea (causing powdery scab of potato), and the vectors of several plant viruses, Polymyxa graminis and Polymyxa betae (Neuhauser et al. 2010). They belong to the Plasmodiophorida (class Phytomyxea); obligate biotrophic pathogens unable to be grown in axenic culture. As discussed by Ngo et al. (2018) P. venanatans belongs to Cercomonadida, making it taxonomically and biologically distinct from the other rhizarian plant pathogens.

Many free-living heterotrophic flagellates must be grown in xenic cultures containing living bacteria (for example, Schuster and Pollak 1978). Plant sources such as cereal leaf extract (Cerophyll), wheat grains, or rice starch are common protist media inclusions (see https://www.ccap.ac.uk and https://www.atcc.org for recipes); however, we have been able to achieve axenic culture on plant-based microbiological media alone. Attempts to culture the organism on solid agar media have been unsuccessful (data not shown), which may explain why earlier researchers were unable to successfully isolate the causal agent using traditional microbiology isolation techniques.

We have successfully established cultures of $P$. venanatans from three sugarcane cultivars, RP193-67, Q238( ${ }^{b}$, and Empire, originally sourced from different locations across the Australian sugar industry. The initial attempts to isolate and culture the pathogen were done with the S8 broth medium devised by Davis et al. (1980). This is a highly complex medium designed to support growth of the fastidious bacterium Leifsonia xyli subsp. xyli that lives within the xylem of sugarcane plants. Because the chlorotic streak causing pathogen appears to live in the same environment, we theorized that this medium could also support growth of the pathogen. However, we found that the cultures could only be successfully subcultured once in S8, and when subcultured again, showed a large drop in the rate of multiplication, while a third successive subculture from the original stalk isolation was generally not successful. Subsequently, we found that the organism will grow successfully in common plant-extract broth media including corn meal and potato dextrose. Potato dextrose broth supplemented with peptone supported the highest growth rates during several subcultures, providing the cells are subcultured during the peak growth phase of 7 to 14 days. Cells have been observed to divide and some cells briefly display four flagella (Ngo et al. 2018). Because the organism will only grow in broth cultures, the contamination rate can be fairly high, with yeast the most common contaminant, usually becoming apparent within about 2 days. Addition of antibiotics to control contaminants has not been investigated but we would expect this to be successful. The ability to reliably produce large amounts of the pathogen will greatly assist production of inoculum for cultivar screening experiments and studies on the interaction of the pathogen with the plant.

Initiation of cultures is relatively easy, although the ability of individual cultures to establish high cell numbers can vary. We attribute this to the apparent variable distribution of the pathogen within stalks and compensated by taking samples from multiple sections of stalk. We have observed flagellated cells of $P$. venanatans in xylem exudates, suggesting that it moves within xylem vessels (Ngo et al. 2018), but we have not yet determined if the organism is confined to the xylem or also present in other cells within infected plants. It is yet to be determined how the pathogen moves through the stalk but the uneven distribution revealed by qPCR is supported by field observations that not all buds from diseased stalks produce diseased plants (Egan 1989).

We have been able to take the cultured cells of the pathogen and infect sugarcane which subsequently resulted in the appearance of the characteristic symptoms of chlorotic streak, and then reisolate for the second time, thus demonstrating Koch's postulates. Infection has been achieved using cultures derived from several sugarcane cultivars and through inoculation of roots, stalks and leaf whorls. Successful infection could be replicated, even with slight procedural modifications, showing that the infection methods are simple, adaptable and reliable. The technique of injection to transmit the disease to healthy plants is not new. Sturgess (1961) reported that limited transmission could be achieved when the roots of healthy plants were inoculated directly by means of a fine hypodermic needle or by immersion of the intact root system for 7 days with diluted diseased root extracts.

By inoculating roots, stalks and leaf whorls, we have demonstrated that the pathogen can move from the roots throughout the whole stalk, from the base of stalk throughout existing higher nodes and move from the leaf whorls down into the stalk, confirming that $P$. venanatans is systemic in sugarcane. PCR screening of infected sugarcane from the field showed variable distribution of the pathogen in the stalk, but PCR screening of experimentally infected material found the pathogen in all samples. In some experiments the symptoms obtained were severe, probably due to the use of inoculum concentrations much higher than what would occur in nature. To date, we have not attempted to optimize the inoculum concentration and this important parameter remains to be determined. For all three tissue types, symptoms were generated within a matter of weeks to months. This offers the potential to develop a glasshousebased screening method to obtain disease resistance ratings for sugarcane cultivars. Where chlorotic streak is a serious problem, the use of resistant cultivars, hot water treatment of seed cane and improving field drainage are the recommended disease management options. Until now, there has been no reliable method to screen cultivars for resistance to chlorotic streak due to the difficulty of setting up replicated screening trials in the field where flooding events and inoculum levels cannot be controlled (Magarey et al. 2006). Magarey et al. (2016) recently established a glasshousebased hydroponic screening approach to overcome field-based problems by replicating methods developed in the 1960s (Egan 1965). Now that techniques are available to visualize, isolate and quantify the organism experimentally, we can begin to address

TABLE 4. Transmission results for RP193-67 plants inoculated with Phytocercomonas venanatans into the leaf whorl

\begin{tabular}{lcc}
\hline Inoculation method & $\begin{array}{c}\text { Test plants } \\
\text { with chlorotic } \\
\text { steak symptoms }\end{array}$ & $\begin{array}{c}\text { Reisolation of } \\
P \text {. venanatans } \\
\text { from test plants }\end{array}$ \\
\hline Control (no inoculation) & $0 / 2$ & $0 / 2$ \\
Apply to cut surface of leaf whorl & $3 / 3$ & $3 / 3$ \\
Injection into leaf whorl & $1 / 3$ & $1 / 3^{\mathrm{a}}$ \\
\hline
\end{tabular}

a Reisolation of $P$. venanatans was only attempted from the plant with chlorotic streak symptoms. 
questions such as how the organism infects naturally though the roots, how it lives within the plant and causes disease, how cells are released back into the soil and how the organism survives for extended periods outside of the plant.

\section{ACKNOWLEDGMENTS}

We thank M. Singh and P. Wickramasinghe for their excellent technical assistance, and R. Magarey, K. Sventek, and staff at SRA Woodford for assistance with the research.

\section{LITERATURE CITED}

Abbott, E. V., and Ingram, J. W. 1942. Transmission of chlorotic streak of sugar cane by the leafhopper Draeculacephala portola. Phytopatholology 32:99-100.

Antoine, R. 1957. Cane diseases 1. Chlorotic streak. Pages 53-57 in: Mauritius Sugar Industry Research Institute Annual Report.

Bird, J., Cibes, H., and Tio, M. A. 1958. Transmission of the causal agent of the chlorotic streak disease of sugar cane through the roots of plants grown in nutrient solution. Univ. Puerto Rico, Agric. Exp. Stn. Tech. Paper No. 27.

Braithwaite, K. S., and Croft, B. J. 2013. A diagnostic test for chlorotic streak disease. Proc. Aust. Soc. Sugar Cane Technol. 35:(electronic format).

Carpenter, C. W. 1940. A chytrid in relation to chlorotic streak disease of sugarcane. The Hawaiian Planters'. Rec. 44:19-33.

Croft, B. J. 2002. A method for rating sugarcane cultivars for resistance to ratoon stunting disease based on an enzyme-linked immunoassay. Australas. Plant Pathol. 31:63-66.

Davis, M. J., Gillaspie, A. G., Jr., Harris, R. W., and Lawson, R. H. 1980. Ratoon stunting disease of sugarcane: Isolation of the causal bacterium. Science 210:1365-1367.

Egan, B. T. 1965. Chlorotic streak disease investigations into host range and possible sources of resistance. Proc. Int. Soc. Sugar Cane Technol. 12: 1055-1059.

Egan, B. T. 1989. Chlorotic streak. Pages 247-262 in: Diseases of Sugarcane-Major Diseases. C. Ricaud, B. T. Egan, A. G. Gilaspie Jr., and C. G. Hughes, eds. Elsevier, Amsterdam.
Magarey, R. C. 2005. The incidence of sugarcane diseases in Queensland. Proc. Aust. Soc. Sugar Cane Technol. 27:252-265.

Magarey, R. C., Finlayson, W. A., and Bull, J. I. 2006. Developments in chlorotic streak resistance screening. Proc. Aust. Soc. Sugar Cane Technol. 28:336-344.

Magarey, R. C., and Neilsen, W. 2002. Chlorotic streak: A disease reducing sugarcane yields in Queensland. Proc. Aust. Soc. Sugar Cane Technol. (CD-ROM) 24.

Magarey, R. C., Sventek, K., Bull, J. I., and Braithwaite, K. S. 2016. Chlorotic streak transmission and crop dynamics research. Proc. Aust. Soc. Sugar Cane Technol. 38:126-134.

Martin, J. P. 1935. Chlorotic streak disease of sugar cane. Proc. Int. Soc. Sugar Cane Technol. 5:823-828.

Neuhauser, S., Bulman, S., and Kirchmair, M. 2010. Plasmodiophorids: The challenge to understand soil-borne, obligate biotrophs with a multiphasic life cycle. Pages 51-78 in: Molecular Identification of Fungi. Y. Gherbawy and K. Voigt, eds. Springer-Verlag, Berlin.

Ngo, C. N., Braithwaite, K. S., Bass, D., Young, A. J., and Croft, B. J. 2018 Phytocercomonas venanatans, a new species of Cercozoa associated with chlorotic streak of sugarcane. Phytopathology doi.org/10.1094/Phyto-0717-0237-R

Pearson, S. J., Chakraborty, S., Croft, B. J., and Irwin, J. A. G. 1996. Histopathology of Pachymetra chaunorhiza and Pythium arrhenomanes. Pages 153-154 in: Sugarcane: Research Towards Efficient and Sustainable Production. J. R. Wilson, D. M. Hogarth, J. A. Campbell, and A. L. Garside, eds. CSIRO Division of Tropical Crops and Pastures, Brisbane.

Schuster, F. L., and Pollak, A. 1978. Ultrastructure of Cercomonas sp., a freeliving ameboid flagellate. Arch. Protistenkd. 120:206-212.

Sturgess, O. W. 1961. Investigations into chlorotic streak disease. Sugar y Azucar July 1961:29.

White, T. J., Bruns, T., Lee, S., and Taylor, J. 1990. Amplification and direct sequencing of fungal ribosomal RNA genes for phylogenetics. Pages 315-322 in: PCR Protocols: A Guide to Methods and Applications. M. A. Innis, D. H. Gelfand, J. J. Sninsky, and T. J. White, eds. Academic Press, San Diego.

Zhu, L., Zhang, J., Chen, Y., Pan, H., and Ming, R. 2013. Identification and genes expression analysis of ATP-dependent phosphofructokinase family members among three Saccharum species. Funct. Plant Biol. 40: 369-378. 